\title{
The Effects of Subacute Ruminal Acidosis on Sodium Bicarbonate- Supplemented Water Intake for Lactating Dairy Cows
}

\author{
G. Cottee, ${ }^{1}$ I. Kyriazakis, ${ }^{2}$ T. M. Widowski, ${ }^{1}$ M. I. Lindinger,${ }^{3}$ J. P. Cant, ${ }^{1}$ T. F. Duffield, ${ }^{4}$ \\ V. R. Osborne, ${ }^{1}$ and B. W. McBride ${ }^{1}$ \\ ${ }^{1}$ Department of Animal and Poultry Science, University of Guelph, \\ Guelph, Ontario, Canada N1G 2W1 \\ ${ }^{2}$ Animal Nutrition and Health Department, Animal Biology Division, \\ Scottish Agricultural College, King's Buildings, West Mains Road, \\ Edinburgh, UK EH9 3JG \\ ${ }^{3}$ Department of Human Biology and Nutritional Sciences, \\ University of Guelph, Guelph, Ontario, Canada N1G 2W1 \\ ${ }^{4}$ Department of Population Medicine, University of Guelph, \\ Guelph, Ontario, Canada N1G 2W1
}

\begin{abstract}
Four multiparous ruminally fistulated Holstein dairy cows were used in an 8-wk experiment utilizing a repeated measures block design to determine the effects of subacute ruminal acidosis (SARA) on supplemented water intake. Animals were subjected to SARA, which was induced by replacing $25 \%$ of the ad libitum intake of the total mixed ration (dry matter basis) with 50:50 wheat:barley pellets utilizing a grain challenge model. Cows had free choice from 2 water bowls. One bowl contained water with sodium bicarbonate (SB) supplemented at $2.5 \mathrm{~g} / \mathrm{L}$. The other bowl contained unsupplemented water. Ruminal $\mathrm{pH}$ was monitored continuously during the trial using indwelling $\mathrm{pH}$ probes. The induction of SARA reduced daily mean ruminal $\mathrm{pH}$ and increased the duration when ruminal $\mathrm{pH}$ was below 6 . The total mixed ration intake by the cows decreased during the SARA periods. The overall preference for SBsupplemented water did not change, as the preference ratio was similar during the control and SARA periods. During the period of greatest ruminal $\mathrm{pH}$ depression, total water intake was higher during the SARA periods than during the control periods. During SARA, there was no difference in the preference of a SB water source to unsupplemented water. During the period of day with the most severe ruminal $\mathrm{pH}$ depression, the lactating dairy cows subjected to SARA increased their total water intake.
\end{abstract}

(Key words: dairy cow, ruminal acidosis, water, choice)

Abbreviation key: $\mathbf{P R}=$ preference ratio, $\mathbf{S A R A}=$ subacute ruminal acidosis, $\mathbf{S B}=$ sodium bicarbonate .

Received May 14, 2003.

Accepted November 28, 2003.

Corresponding author: G. Cottee; e-mail: gcottee@uoguelph.ca.

\section{INTRODUCTION}

Researchers have demonstrated that ruminants select feeds varying in composition and physical form to compensate for nutritional deficiencies and metabolic disorders (Provenza, 1995; Cooper et al., 1996; Keunen et al., 2003). Cattle and sheep will select to reduce intake of poor quality feeds and avoid feeds that may be harmful or toxic (Rankins et al., 1993; Cooper et al., 1994). Cattle and sheep can also utilize dietary choice to counteract imbalances within the rumen environment (Cooper and Kyriazakis, 1995; Keunen et al., 2003).

To meet the increasing demands for nutrients during early lactation, diets high in fermentable carbohydrates are fed to high producing dairy cows. These diets decrease ruminal $\mathrm{pH}$ because of increased concentrations of VFA and lactic acid (Underwood, 1992). Subacute ruminal acidosis (SARA) occurs when ruminal $\mathrm{pH}$ is depressed between a minimum $\mathrm{pH}$ of 5.2 and 5.6 (Cooper and Klopfenstein, 1996) and is characterized by decreased DMI, decreased milk production, diarrhea, and an increased incidence of laminitis (Nocek, 1997).

Sodium bicarbonate (SB) is an important buffer of ruminal pH (Erdman, 1988). Sodium bicarbonate enters the rumen through increased salivation during chewing and is routinely added to dairy cow rations to prevent a decrease in ruminal pH (Erdman, 1988; Kohn and Dunlap, 1998). Additionally, Cooper et al. (1996) found that sheep fed diets that depress $\mathrm{pH}$ chose pellets containing SB vs. pellets without.

Water has been used as a medium to deliver many supplements such as minerals for poultry (Shlosberg et al., 1998; Yoselewitz et al., 1990), sodium chloride for rats (Kraly et al., 1995; Rowland et al., 1995), and glucose for the transition dairy cows (Osborne et al., 2002). Sodium bicarbonate is commonly added to water as the key ingredient in drenches to increase bloodbuffering capacity of race horses (Freestone et al., 1989; 
Lloyd and Rose, 1995). Several experiments have been conducted with dietary choice and ruminal acidosis in sheep (Cooper et al., 1996; Phy and Provenza, 1998a,b). The idea of supplementing water with SB and offering it as a choice to dairy cows subjected to SARA has not been previously reported. The hypothesis was that the lactating dairy cow subjected to SARA would select drinking water supplemented with SB to attenuate this condition. The effect of SARA on water intake was examined, and the dairy cows' preference for SB-supplemented and unsupplemented water while subjected to SARA was determined.

\section{MATERIALS AND METHODS}

\section{Animals and Experimental Procedures}

Four multiparous, ruminally fistulated Holstein dairy cows (693 $\pm 114 \mathrm{~kg} \mathrm{BW} ; 142 \pm 20 \mathrm{DIM})$ were housed in individual tie stalls at the Elora Dairy Research Centre (University of Guelph, Guelph, ON). The experimental procedures were performed in accordance with the University of Guelph Animal Care Policy and Canadian Council on Animal Care Guidelines (1993).

Cows were allocated to an 8-wk experiment utilizing a repeated measures block design. The experiment was conducted from June through August 2001. Each week consisted of 5 supplementation (sampling) days (d 1 to 5) and 2 non-sampling days (d 6 to 7). Each of the 4 wk when SARA occurred was preceded by a non-SARA or control week.

Control diets were fed for ad libitum intake during wk 1, 3, 5, and 7. The SARA induction diets were fed on wk 2, 4, 6, and 8. A single TMR (Table 1) was fed for ad libitum intake twice daily at 0700 and $1700 \mathrm{~h}$ during wk 1, 3, 5, and 7. During wk 2, 4, 6, and 8, 25\% of the total TMR (DM basis) was replaced with 50:50 wheat:barley pellets to induce SARA as per the method developed by Keunen et al. (2002) (Figure 1). During wk 2, 4, 6, and 8, TMR was restricted to a $2-\mathrm{kg}$ DM basis at $0700 \mathrm{~h}$. Two 0.5 -h free choice TMR feeding intervals occurred between 1100 and $1130 \mathrm{~h}$ and between 1500 and $1530 \mathrm{~h}$. Subacute ruminal acidosis was induced by providing wheat:barley pellets at $0900 \mathrm{~h}(2 / 3$ of daily total or approximately $4 \mathrm{~kg}$ ) and at $1300 \mathrm{~h}$ (remaining $1 / 3$ of daily total or approximately $2 \mathrm{~kg}$ ). The TMR was offered again for ad libitum intake at $1700 \mathrm{~h}$.

\section{Measurements}

During the experiment, animals had free choice from 2 laterally positioned water bowls, i.e., left and right side. One water bowl contained unsupplemented water. The opposite bowl contained water with SB supplemented at $2.5 \mathrm{~g} / \mathrm{L}$. The position of the supplemented
Table 1. Ingredient composition and dietary analysis for experimental diets.

\begin{tabular}{lcl}
\hline Item & TMR & Wheat:barley pellet \\
\hline Ingredient, \% as fed & & \\
Corn silage & 43.3 & - \\
Alfalfa silage & 10.2 & - \\
High-moisture corn & 22.7 & - \\
Mixed hay & 5.2 & - \\
Supplement ${ }^{1}$ & 18.6 & - \\
Ground wheat & - & 50 \\
Ground barley & - & 50 \\
Chemical analysis & & \\
DM, \% & 44.2 & 87.3 \\
CP,\% of DM & 21.4 & 12.5 \\
NDF, \% of DM & 35.8 & 16.4 \\
ADF, \% of DM & 22.2 & 4.2 \\
Ca, \% of DM & 1.05 & 0.04 \\
P, \% of DM & 0.49 & 0.40 \\
K, \% of DM & 1.78 & 0.54 \\
Mg, \% of DM & 0.40 & 0.14 \\
$\mathrm{Na} \%$ of DM & 0.20 & 0.02 \\
\hline
\end{tabular}

${ }^{1}$ Contained (as-fed basis) $6.90 \%$ blood meal, $14.79 \%$ canola meal, $14.58 \%$ corn gluten meal, $23.41 \%$ soybean meal, $1.97 \%$ Megalac (Church \& Dwight, Princeton, NJ), 0.79\% Biophos, 4.34\% calcium carbonate, $1.38 \%$ salt, $0.39 \%$ Dynamate (IMC Feed Ingredients, Lake Forest, IL), $0.20 \%$ yeast (Diamond V, Cedar Rapids, IA), 0.35\% FFM [dicalcium phosphate, calcium carbonate, magnesium oxide, trace minerals, and vitamins A, D, and E (Flordale Feedmill, Flordale, ON, Canada)], 7.89\% wheat shorts, $3.13 \%$ fish meal, $3.68 \%$ molasses, 0.35\% Alimet DL-Methionine Hydroxy Analogue, (Novus, St. Louis, $\mathrm{MO}), 9.86 \%$ soybean whole roast, $0.79 \%$ potassium carbonate, $0.30 \%$ Fibrozyme (Alltech, Nicholasville, KY), and $0.30 \%$ urea.

and unsupplemented water was initially randomly allocated and switched at the experimental design midpoint, i.e., if supplemented water was delivered to left bowl for the first 4-wk period, it would then be delivered to the right bowl for the final 4-wk period.

Water intake was measured continuously during this trial. Each stall was equipped with 2 Colorado stainless steel water bowls (Alfa Laval Agri. Inc., Peterborough, ON, Canada). A bowl was positioned $0.5 \mathrm{~m}$ above the ground on both the right and left side of the tie stall. Well water (see Table 2 for chemical analysis) was supplied to each water bowl. Supplementation of SB was provided via 2 in-line liquid injectors (Models DI 150 and DI 16-11GPM; Dosatron International, France) that injected a SB solution achieving a final concentration of $2.5 \mathrm{~g} / \mathrm{L}$. The flow rate to each bowl could be adjusted. The water bowls were connected to a $\mathrm{C} 700$ B-Pulse in-line water meter (ABB Water Meters Inc., Mississauga, ON, Canada). A pulse was generated $1 \times /$ L consumed and sent by switch closure through 18ga. wire to a data logger (CR10X; Campbell Scientific, Edmonton, AB, Canada). Software collected data and recorded totals every $15 \mathrm{~min}$, hourly and daily.

Individual preference ratios (PR) for supplemented water vs. unsupplemented water intake were calculated as: $\mathrm{PR}=$ supplemented water intake/total water 


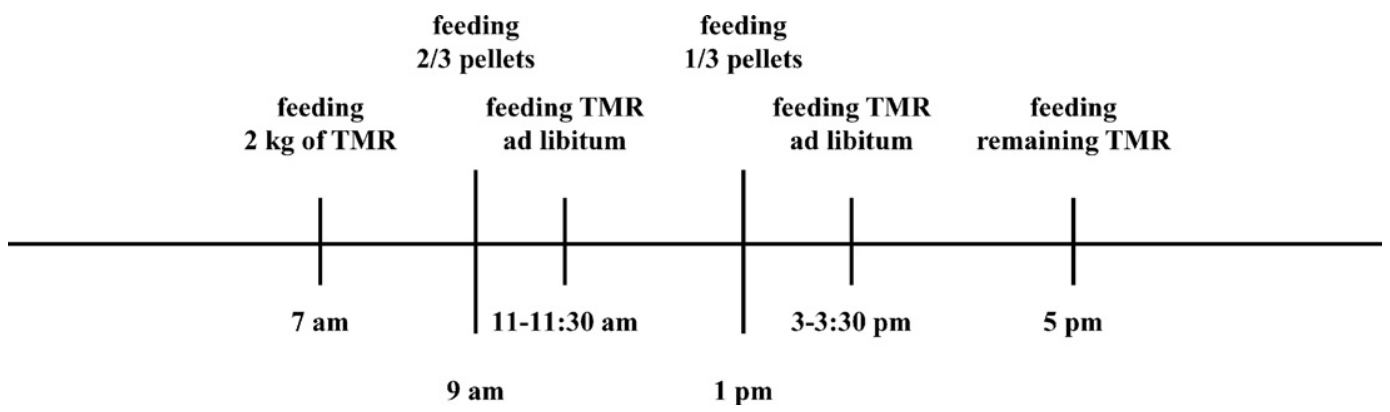

Figure 1. Daily feeding schedule for the induction of subacute ruminal acidosis in Holstein dairy cows.

intake. The PR values were calculated for both the control and the SARA periods and for the daily 3 -h period of maximum ruminal $\mathrm{pH}$ depression.

Water samples were collected weekly from non-supplemented and SB-supplemented water sources. Water samples were analyzed at Agri-Food Laboratories (Guelph, ON, Canada). Water was analyzed for $\mathrm{pH}$, total salts, total hardness, bicarbonates, minerals, sulfates, and phosphorus (AOAC, 1990); total solids (Gravimetric); chloride (ion-specific electrode); and nitrates (Technicon-Cadmium reduction/Spectrophotometric analysis). The ground water in this area is hard, containing high levels of calcium carbonate.

At the midpoint of the experiment, the 2 different types of water presented had their position switched, i.e., if the bicarbonate water was delivered originally in the left bowl it was altered to right bowl and vice versa for the unsupplemented water, which provided the opportunity to determine whether the animals could detect the presence of the 2 different types of

Table 2. Drinking water chemical analysis (nonsupplemented water).

\begin{tabular}{lrl}
\hline Water component & Mean & $\mathrm{SE}$ \\
\hline $\mathrm{pH}$ & 8.11 & 0.08 \\
Nitrate N, mg/kg & 5.00 & 0.80 \\
Total hardness, mg/kg & 228.75 & 5.32 \\
Total solids, \% & 0.09 & 0.06 \\
Bicarbonate, mg/kg & 294.00 & 8.13 \\
Sulfates, mg/kg & 37.48 & 1.04 \\
$\mathrm{P}, \mathrm{mg} / \mathrm{kg}$ & 0.10 & $0.00^{1}$ \\
$\mathrm{~K}, \mathrm{mg} / \mathrm{kg}$ & 0.61 & 0.24 \\
$\mathrm{Ca}, \mathrm{mg} / \mathrm{kg}$ & 54.54 & 1.05 \\
$\mathrm{Mg}, \mathrm{mg} / \mathrm{kg}$ & 22.47 & 0.68 \\
$\mathrm{Cl}, \mathrm{mg} / \mathrm{kg}$ & 3.89 & 0.56 \\
$\mathrm{Na}, \mathrm{mg} / \mathrm{kg}$ & 22.32 & 2.40 \\
$\mathrm{Zn}, \mathrm{mg} / \mathrm{kg}$ & 0.05 & 0.01 \\
$\mathrm{Mn}, \mathrm{mg} / \mathrm{kg}$ & 0.01 & $0.00^{1}$ \\
$\mathrm{Cu}, \mathrm{mg} / \mathrm{kg}$ & 0.09 & 0.17 \\
$\mathrm{Fe}, \mathrm{mg} / \mathrm{kg}$ & 0.01 & 0.002 \\
$\mathrm{~B}, \mathrm{mg} / \mathrm{kg}$ & 0.06 & 0.002 \\
$\mathrm{Si}, \mathrm{mg} / \mathrm{kg}$ & 5.44 & 0.07 \\
\hline
\end{tabular}

${ }^{1}$ Indicates minimum level of detection by laboratory method. water and determine whether the position had an effect on water preference.

Ruminal $\mathrm{pH}$ was monitored continuously during the trial using an adaptation of a technique developed by Dado and Allen (1993). A Sensorex Combi pH Electrode 450 CD (Sensorex, Stanton, CA) was placed through a rumen fistula into the anterior region of the rumen ventral sac. The $\mathrm{pH}$ data were collected every second and an average for each minute was calculated and stored for subsequent analysis (Keunen et al., 2002). For each 24 -h period, ruminal $\mathrm{pH}$ was summarized into daily averages and calculated for time below $\mathrm{pH} 6$, time below 5.6, area under $\mathrm{pH} 6$, and area under $\mathrm{pH}$ 5.6.

The position of the $\mathrm{pH}$ electrodes were checked daily at $0930 \mathrm{~h}$ when manual ruminal samples were taken from the anterior region of the rumen ventral sac. $\mathrm{Ru}-$ minal $\mathrm{pH}$ was measured using a Corning Benchtop $\mathrm{pH}$ meter (Model Corning 220; Corning Inc., Corning, NY) and an Accumet Gel-filtered Polymet Body Combination Electrode (Fisher Scientific, Fairlawn, NJ). Electrodes and $\mathrm{pH}$ transmitters were calibrated once weekly using buffer solutions ( $\mathrm{pH} 4.0$ and 7.0) (Fisher Scientific).

Milk production was recorded daily throughout the experiment. Milk samples were collected 2 times daily at 0500 and $1500 \mathrm{~h}$. Morning and afternoon milk samples were pooled daily based on milk yields. Milk samples were analyzed for fat, protein, and lactose by infrared spectroscopy using the Foss System 400 (Foss Electric, Hillerød, Denmark) at Laboratory Services Division, University of Guelph (Guelph, ON, Canada).

\section{DMI and Feed Analysis}

A weekly composite TMR sample (Table 1) and orts sample were collected for chemical analysis. Orts were weighed every day at $0900 \mathrm{~h}$. Weights of TMR and wheat:barley pellets were recorded daily. Dry matter of feeds and orts were determined by drying in an oven at $60^{\circ} \mathrm{C}$ for $48 \mathrm{~h}$ (AOAC, 1990). The TMR and wheat:bar- 
Table 3. Summary of milk yield, milk components, DMI, and rumen $\mathrm{pH}$ parameters during control and subacute ruminal acidosis (SARA) periods.

\begin{tabular}{lcccc}
\hline & Control & SARA & SE & $P$ \\
\hline DMI, kg/d & 21.4 & 20.0 & 0.4 & 0.01 \\
Milk yield, kg/d & 32.2 & 31.5 & 0.5 & 0.34 \\
Fat, \% & 2.99 & 3.10 & 0.06 & 0.23 \\
Protein, \% & 3.14 & 3.08 & 0.01 & 0.0002 \\
Lactose, \% & 4.73 & 4.73 & 0.01 & 0.96 \\
Mean pH/d & 6.27 & 5.99 & 0.03 & $<0.0001$ \\
Minutes under pH 6.0/d & 337.0 & 654.3 & 31.4 & $<0.0001$ \\
Area under pH 6.0 curve/d & 125.0 & 327.0 & 24.2 & $<0.0001$ \\
Minutes under pH 5.6/d & 127.8 & 345.3 & 26.5 & $<0.0001$ \\
Area under pH 5.6 curve/d & 45.9 & 142.5 & 16.3 & $<0.0001$ \\
\hline
\end{tabular}

ley pellets were analyzed by Agri-Food Laboratory for determination of $\mathrm{CP}$ using the macro-Kjeldahl procedure (AOAC, 1990), ADF (AOAC, 1990; Undersander et al., 1993), NDF (Goering and Van Soest, 1970), and $\mathrm{Ca}, \mathrm{P}, \mathrm{K}, \mathrm{Mg}$, and $\mathrm{Na}$ (AOAC, 1990).

\section{Statistical Design and Model}

Analysis of variance was conducted using the SAS General Linear Models procedure with a repeated measures block design (SAS, 1998). For water intake, the model used was

$\mathrm{Y}_{\mathrm{ijklm}}=\pi+\alpha_{\mathrm{i}}+\beta_{\mathrm{j}}+(\alpha \beta)_{\mathrm{ij}}+\mathrm{T}_{\mathrm{k}}+\tau_{\mathrm{l}}+(\mathrm{T} \tau)_{\mathrm{kl}}+\omega_{\mathrm{m}}+\varepsilon_{\mathrm{ijklm}}$

where

$$
\begin{aligned}
\mathrm{Y}_{\mathrm{ijklm}} & =\text { dependent variable, } \\
\pi & =\text { overall true mean } \\
\alpha_{\mathrm{l}} & =\text { effect of animal }(\mathrm{i}=1,2,3,4), \\
\beta_{\mathrm{j}} & =\text { effect of bowl placement }(\mathrm{j}=1,2), \\
(\alpha \beta)_{\mathrm{ij}} & =\text { effect of animal-bowl interaction, } \\
\mathrm{T}_{\mathrm{k}} & =\text { effect of day }(\mathrm{k}=1,2,3,4,5), \\
\tau_{\mathrm{l}} & =\text { effect of time of day, } \\
(\mathrm{T} \tau)_{\mathrm{kl}} & =\text { effect of day-time of day interaction, } \\
\omega_{\mathrm{m}} & =\text { effect of treatment, and } \\
\varepsilon_{\mathrm{ijklm}} & =\text { random residual error. }
\end{aligned}
$$

For ruminal $\mathrm{pH}$ the model used was

$$
\mathrm{Y}_{\mathrm{ijkl}}=\pi+\alpha_{\mathrm{i}}+\mathrm{T}_{\mathrm{j}}+\tau_{\mathrm{k}}+(\mathrm{T} \tau)_{\mathrm{ik}}+\omega_{\mathrm{l}}+\varepsilon_{\mathrm{ijkl}}
$$

where

$$
\begin{aligned}
\mathrm{Y}_{\mathrm{ijkl}} & =\text { observation on the treatment } \mathrm{I} \text { in block } \\
& \text { ijkl}, \\
\pi & =\text { overall true mean } \\
\alpha_{1} & =\text { effect of animal }(\mathrm{i}=1,2,3,4) \\
\mathrm{T}_{\mathrm{j}} & =\text { effect of day }(\mathrm{j}=1,2,3,4,5) \\
\tau_{\mathrm{k}} & =\text { effect of time of day } \\
(\mathrm{T} \tau)_{\mathrm{ik}} & =\text { effect of day-time of day interaction, } \\
\omega_{1} & =\text { effect of treatment, and } \\
\varepsilon_{\mathrm{ijkl}} & =\text { random residual error. }
\end{aligned}
$$

The data set was tested for normality requiring no transformations. Least square means are reported for comparison of $\mathrm{pH}$ and water parameters between control and SARA periods. Paired t-tests were completed for comparison between PR. A probability level of $(P<$ 0.05) was considered significant.

\section{RESULTS AND DISCUSSION}

Subacute ruminal acidosis has been characterized by daily bouts of $\mathrm{pH}$ depression between 5.2 and 5.6 (Cooper and Klopfenstein, 1996). The nutritional model used for the induction of SARA was previously described by Keunen et al. (2002). With the induction of SARA, the mean daily ruminal $\mathrm{pH}$ was reduced $(P<$ 0.0001 ), and the minutes below $\mathrm{pH} 6.0$ and 5.6 as well as the area below pH 6.0 and 5.6 increased $(P<0.0001)$ (Table 3). The time below 5.6 ensured prolonged expo-

Table 4. Daily water intakes, preference ratios, and bicarbonate intake during control and subacute ruminal acidosis (SARA) periods.

\begin{tabular}{lllll}
\hline & Control & SARA & SE & $P$ \\
\hline Supplemented water, L/d & 33.4 & 32.3 & 2.8 & 0.98 \\
Unsupplemented water, L/d & 49.5 & 46.3 & 2.8 & 0.42 \\
Total water intake, L/d & 81.9 & 78.6 & 2.2 & 0.29 \\
Preference ratio & 0.39 & 0.40 & 0.03 & 0.72 \\
Bicarbonate intake, g/d & 79.7 & 88.7 & 7.5 & 0.40 \\
\hline
\end{tabular}


Table 5. Summary of water intake, preference ratios, and mean ruminal $\mathrm{pH}$ for the 3 -h interval during the day of minimum rumen $\mathrm{pH}$ values during control and subacute ruminal acidosis (SARA) periods.

\begin{tabular}{lcccc}
\hline & Control & SARA & SE & $P$ \\
\hline Supplemented water, L & 5.6 & 6.8 & 0.8 & 0.27 \\
Unsupplemented water, L & 8.8 & 12.1 & 0.8 & 0.005 \\
Total water intake, L & 14.4 & 19.0 & 0.7 & $<0.0001$ \\
Mean pH & 6.02 & 5.45 & 0.1 & $<0.0001$ \\
Preference ratio & 0.39 & 0.36 & 0.04 & 0.63 \\
\hline
\end{tabular}

sure to lowered rumen $\mathrm{pH}$, indicating the severity of the rumen malaise.

Dry matter intake decreased $(P=0.01)$ during SARA when compared with the control period (Table 3). Average daily milk yield, fat content, and lactose content were not different between treatments (Table 3). However, milk protein content decreased $(P=0.0002)$ during SARA when compared with the control period (Table 3 ). The nutritional model successfully subjected the cows to daily bouts of SARA.

Daily water intake is summarized in Table 4. Mean daily water intake remained unaltered during the SARA periods (Table 4). Intakes of both SB-supplemented water and unsupplemented water were also unaltered during the SARA periods (Table 4). The average daily bicarbonate intakes from the SB-supplemented water for the SARA and control periods are summarized in Table 4.

The induction of SARA elicits changes within the rumen environment associated with lowered rumen $\mathrm{pH}$. Kyriazakis et al. (1999) suggested that animals will alter dietary selection in response to a significant physiological change such as altered rumen state. The diurnal pattern of lowered ruminal $\mathrm{pH}$ is exaggerated with SARA, as seen in Keunen et al. (2002), and reaches the most severe $\mathrm{pH}$ decline of the day during the afternoon.

Ruminal $\mathrm{pH}$ depression was at the most severe point for $3 \mathrm{~h}$ during the afternoon period following the second feeding of the wheat:barley pellets (Table 5). During this period, the mean ruminal $\mathrm{pH}$ decreased $(P<0.0001)$ during SARA when compared with the control period. Ruminal $\mathrm{pH}$ increased following a large drinking bout during this afternoon period. During the SARA periods, the ruminal $\mathrm{pH}$ increased $(P<0.05)$ after a drinking bout from $5.67 \pm 0.08$ to $5.91 \pm 0.08$. During the control period, ruminal $\mathrm{pH}$ also increased $(P<0.05)$ after a drinking bout from $6.04 \pm 0.04$ to $6.19 \pm 0.04$. During the 3-h period of maximum $\mathrm{pH}$ depression, total water intake was higher $(P<0.0001)$ during the SARA period than during the control period. In addition, the intake of unsupplemented water increased $(P=0.005)$ during SARA when compared with the control period. The mean PR remained unchanged during the period of maximum ruminal $\mathrm{pH}$ depression (Table 5).
During this period, in the afternoon of maximum ruminal $\mathrm{pH}$ depression, the animals consumed more water. Ruminal $\mathrm{pH}$ increased following drinking bouts during this afternoon period.

\section{CONCLUSIONS}

During SARA, there is no difference in the preference for SB-supplemented water compared with unsupplemented water. During the period of the day when rumi$\mathrm{nal} \mathrm{pH}$ depression is greatest, lactating dairy cows subjected to SARA increase their total water intake.

\section{ACKNOWLEDGMENTS}

The authors acknowledge the Dairy Farmers of Ontario, Ontario Ministry of Agriculture, Food, and Rural Affairs, and the National Sciences and Engineering Research Council of Canada for their financial support of this work.

\section{REFERENCES}

Association of Official Analytical Chemists. 1990. Official Methods of Analysis. 15th ed. AOAC, Arlington, VA.

Canadian Council on Animal Care. 1993. Guide to the Care and Use of Experimental Animals. CCAC, Ottawa, ON, Canada.

Cooper, R., and T. Klopfenstein. 1996. Effect of Rumensin and Feed Intake Variation on Ruminal $\mathrm{pH}$. Scientific Update on Rumensin/ Tylan/ Micotil for the Professional Feedlot Consultant. Elanco Animal Health, Greenfield, IN. A1-A14.

Cooper, S. D. B., and I. Kyriazakis. 1995. Diet selection in sheep: The role of the rumen environment in the selection of a diet from two feeds that differ in their energy density. Br. J. Nutr. 74:39-54.

Cooper, S. D. B., I. Kyriazakis, and J. D. Oldham. 1994. The effect of late pregnancy on diet selections made by ewes. Livest. Prod. Sci. 40:263-275.

Cooper, S. D. B., I. Kyriazakis, and J. D. Oldham. 1996. The effects of physical form of feed, carbohydrate source, and inclusion of sodium bicarbonate on the diet selections of sheep. J. Anim. Sci. 74:1240-1251.

Dado, R. G., and M. S. Allen. 1993. Continuous computer acquisition of feed and water intakes, chewing, reticular motility and rumen $\mathrm{pH}$ of cattle. J. Dairy Sci. 76:1589-1600.

Erdman, R. A. 1988. Dietary buffering requirements of the lactating dairy cow: A review. J. Dairy Sci. 71:3246-3266.

Freestone, J. F., G. P. Carlson, D. R. Harrold, and G. Church. 1989. Furosemide and sodium bicarbonate-induced alkalosis in the horse and response to oral $\mathrm{KCl}$ or $\mathrm{NaCl}$ therapy. Am. J. Vet. Res. 50:1334-1339.

Goering, H. K., and P. J. Van Soest. 1970. Forage Fiber Analyses (Apparatus, Reagents, Procedures, and Some Applications). Agric. Handbook No. 379. ARS-USDA, Washington, DC. 
Keunen, J. E., J. C. Plaizer, I. Kyriazakis, T. F. Duffield, T. M. Widowski, M. I. Lindinger, and B. W. McBride. 2002. Effects of a subacute ruminal acidosis model on the diet selection of dairy cows. J. Dairy Sci. 85:3304-3313.

Keunen, J. E., J. C. Plaizer, I. Kyriazakis, T. F. Duffield, T. M. Widowski, M. I. Lindinger, and B. W. McBride. 2003. Short communication: Effects of subacute ruminal acidosis on free-choice intake of sodium bicarbonate in lactating dairy cows. J. Dairy Sci. 86:954-957.

Kohn, R. A., and T. F. Dunlap. 1998. Calculation of the buffering capacity of bicarbonate in the rumen and In Vitro. J. Anim. Sci. 76:1702-1709.

Kraly, F. S., Y. Kim, L. M. Dunham, and R. A. Tribuzio. 1995. Drinking after intragastric $\mathrm{NaCl}$ without increase in systemic plasma osmolality in rats. Am. J. Physiol. 269(38):R1085-R1092.

Kyriazakis, I., B. J. Tolkamp, and G. Emmans.1999. Diet selection and animal state: an integrative framework. Proc. Nutr. Soc. $58: 765-772$

Lloyd, D. R., and R. J. Rose. 1995. Effects of sodium bicarbonate on fluid, electrolyte and acid-base balance in racehorses. Br. Vet. J. 151:523-545.

Nocek, J. E. 1997. Bovine acidosis: Implications on laminitis. J. Dairy Sci. 80:1005-1028.

Osborne, V. R., K. E. Leslie, and B. W. McBride. 2002. Effect of supplementing glucose in drinking water on the energy and nitrogen status of the transition dairy cow. Can. J. Anim. Sci. 82:427-433.

Phy, T. S., and F. D. Provenza. 1998a. Sheep fed grain prefer foods and solutions that attenuate acidosis. J. Anim. Sci. 76:954-960.
Phy, T. S., and F.D. Provenza. 1998b. Eating barley too frequently or in excess decreases lambs' preference for barley but sodium bicarbonate and lasalocid attenuate the response. J. Anim. Sci. 76:1578-1583.

Provenza, F. D. 1995. Postingestive feedback as an elementary determinate of food preference and intake in ruminants. J. Range Manage. 48:2-17.

Rankins, D. L., Jr., G. S. Smith, T. T. Ross, J. S. Caton, and P. Kloppenburg. 1993. Characterization of toxicosis in sheep dosed with blossoms of sacahuiste (Nolina microcarpa). J. Anim. Sci. 71:2489-2498.

Rowland, N. E., K. R. Morian, T. M. Nicholson, and J. J. Salisbury. 1995. Preference for $\mathrm{NaCl}$ solutions in sham drinking SpragueDawley rats: Water deprivation, sodium depletion, and angiotensin II. Physiol. Behav. 57:753-757.

SAS User's Guide. Version 7. 1998. SAS Inst., Inc., Cary, NC.

Shlosberg, A., M. Bellaiche, E. Berman, A. B. David, N. Deeb, and A. Cahaner. 1998. Comparative effects of added sodium chloride, ammonium chloride or potassium bicarbonate in the drinking water of broilers, and feed restriction, on the development of the ascites syndrome. Poult. Sci. 77:1287-1296.

Underwood, W. J. 1992. Rumen lactic acidosis. Part 1. Epidemiology and pathophysiology. Compend. Contin. Educ Pract. Vet. 14:1127-1133.

Undersander, D., D. R. Mertens, and N. Theix. 1993. Forage Analyses Procedures. National Forage Testing Association. Omaha, NE.

Yoselewitz, I., D. Zhang, and D. Balnave. 1990. The effect on eggshell quality of supplementing saline drinking water with sodium or ammonium bicarbonate. Aust. J. Agric. Res. 41:1187-1192. 